\title{
ReSEARChArticle
}

\section{Response of finger millet (Eleusine coracana L.) cultivated on steep hill slopes to foliar nutrition}

\author{
A.V. Bulbule, P.N. Gajbhiye and C.T. Kumbhar
}

\section{SUMMARY}

Field experiments were conducted at Zonal Agricultural Research Station, Shenda Park Farm, Kolhapur on Entisol, Submontane Zone of Maharashtra during the Kharif seasons of 2014 to 2016 to study the response of finger millet crop to foliar nutrition of nitrogen, phosphorus and potassium. The finger millet was transplanted and fertilized by basal general recommended dose of fertilizer ( $45 \mathrm{~kg} \mathrm{~N}: 22.5 \mathrm{~kg} \mathrm{P}_{2} \mathrm{O}_{5}: 00 \mathrm{~kg} \mathrm{~K}_{2} \mathrm{O}$ through briquettes) + FYM @ $5 \mathrm{t} \mathrm{ha}^{-1}$. Foliar spray was applied at 50 days after transplanting. The fertilizers used for spray were urea, di-ammonium phosphate, muriate of potash, complex 19-19-19 and calcium nitrate applied @ 2\% foliar spray while combination treatment of urea, di-ammonium phosphate and muriate of potash @ $0.5 \%$ each was applied to the experimental plots.The findings of the field experiments revealed that the application of foliar spray increased the yields of finger millet crop. The highest yield was recorded by the treatment foliar spray of 19-19-19 @ 2\% (22.68 q ha-1) over the recommended dose of fertilizer $\left(17.75 \mathrm{q} \mathrm{ha}^{-1}\right)$. It was followed by the treatment urea spray applied @ $2 \%\left(20.86 \mathrm{q} \mathrm{ha}^{-1}\right)$, DAP @ $2.0 \%\left(19.85 \mathrm{q} \mathrm{ha}^{-1}\right)$ and at par with rest of the treatments on foliar nutrition while it was superior over water spray $\left(17.94 \mathrm{q} \mathrm{ha}^{-1}\right)$. The similar trend was observed by straw yield of finger millet crop to that of grain yield. The data on plant uptake revealed that the treatment of foliar spray 19-19-19 @ 2\% recorded higher uptake of N, P and K as compared to no foliar spray application. The application of foliar spray 19-19-19 @ 2\% recorded significantly highest B:C ratio (1.46). The soil analyses after harvest of the crop revealed that the nitrogen, phosphorus and potassium contents in the soil after harvest of the crop did not differ amongst the different treatments.

Key Words : Foliar, Finger millet, Nutrient, Rice, Yield

How to cite this article : Bulbule, A.V., Gajbhiye, P.N. and Kumbhar, C.T. (2018). Response of finger millet (Eleusine coracana L.) cultivated on steep hill slopes to foliar nutrition. Internat. J. Plant Sci., 13 (1): 183-187, DOI: 10.15740/HAS/IJPS/ 13.1/183-187.

Article chronicle : Received : 27.11.2017; Revised : 11.12.2017; Accepted : 25.12.2017 